\title{
English Vowels and Consonants Mispronunciation of the Seventh President of Republic of Indonesia in His Official English Speeches and Its Influencing Factors
}

\author{
Ambalegin $^{1}$, Tomi Arianto ${ }^{2}$ \\ ${ }^{1,2}$ English Literature, Universitas Putera Batam \\ Batam, Indonesia \\ e-mail: abhi140475@gmail.com
}

Received: 19 September 2018

Accepted: 29 September 2018

\begin{abstract}
This research aimed to find out the mispronunciation of English vowels and consonants of the seventh president of Republic of Indonesia, Mr. Joko Widodo in his official English speeches based on the standard of British English Received Pronunciation (RP) and the factors influencing his English vowels and consonants mispronunciation. This research is a descriptive qualitative research. In collecting data, the researchers used observation method with non-participatory technique (Sudaryanto, 2015). In analyzing the data, the researchers used articulatory identity method (Sudaryanto, 2015). It was found that the consonant sounds $/ \theta /, / \delta /, / \mathrm{v} /, / \mathrm{z} /, / \mathrm{J} /$ were pronounced incorrectly, the vowel sounds/ə/, /o/, / / /, /i/, /e/, /I/ were pronounced inconsistently, and the diphthong sounds /rə/, /eI/, /əఠ/ and /av/ were pronounced incorrectly. The consonant sound /I/ in the middle of the word was not pronounced. The consonant sound $/ \mathrm{j} /$ in the middle of the word is omitted. The consonant sounds $/ \mathrm{g} /, / \mathrm{t} / \mathrm{l}$, and $/ \mathrm{r} /$ were pronounced the same as the spelling. The consonant sounds $/ \mathrm{t} /, / \mathrm{s} / \mathrm{,} / \mathrm{k} /$ at the end of the words were omitted. The letter $y$ sounded /I/ at the end of the word was pronounced as /e/. The diphthong sounds/ıə/, /eI/, /əv/ and /av/ were pronounced as $/ \mathrm{I} /, / \Lambda /, / \varepsilon /, / \partial /, / \mathrm{e} /$, and $/ \mathrm{J} /$. The factors influencing the mispronunciation of English vowel and consonant sounds were mother tongue interference, sound system differences between Indonesian and English, the influence of spelling on pronunciation, educational background, and environmental background.
\end{abstract}

Keywords: Received Pronunciation, mispronunciation, interference.

\section{Introduction}

Most of the people communicate or convey their idea or information through oral way and produce sounds when preaching, speaking, and singing. Finegan $(2015$, p. 7$)$ stated, "the most common vehicle of linguistic communication is the voice, and speech is thus a primary mode of human language, with some advantages over other modes". As mentioned by Finegan (2015, p. 16), "human voice has volume, pitch, rhythm, and speed; it is capable of wide-ranging modulation". In oral way all elements must be involved, and according to Ambalegin, Suhardianto, \& Kaprawi (2017, p. 122), there are five elements of speaking such as pronunciation, grammar, vocabulary, fluency, and comprehension. 
English Vowels and Consonants Mispronunciation of the Seventh President of Republic of Indonesia in His Official English Speeches and Its Influencing Factors, Ambalegin, Tomi Arianto

Pronunciation is one of the important elements to convey idea or information in terms of oral way. Pronunciation is the manner where someone utters a word. Gilakjani (2016, p. 2) stated, "Pronunciation is the way of uttering a word in an accepted manner". He further stated, "Pronunciation instruction is very important for oral communication, and it is also a significant part of communicative competence".

Every different language has its own different pronunciation. The way to pronounce the words of Indonesian is different from that of English. The number of letters of the alphabet is simply put together to form the words. In Indonesian, every letter is a phonetic symbol representing one sound and each sound has its appropriate symbol. For example, Indonesians pronounce buku as /buku/. On the contrary, in English most written words are pronounced differently. Each sound of English is presented by more than one written letter or by sequences of letters and any letter of English represents more than one sound, or it may not represent any sound at all. For example, the word cut is pronounced as $/ \mathrm{k} \wedge \mathrm{t} /$. The difference of pronunciation in Indonesian from that in English will greatly affect in oral way. Thus, Indonesians will find difficulties in pronouncing English sounds. English as a foreign language (EFL) is taught in schools in Indonesia. Yulia (2014, p. 4) stated that knowing English is a gate to the world of business, technology, sciences, and travel. People learn English to support their activities and carrier such as doing business, having meeting either nationally or internationally, and attending international conferences.

As the seventh president of Republic of Indonesia, Mr. Joko Widodo has to meet the world, give speeches, and socialize globally. As a president, he is supposed to master English. He delivered the English speeches well, but in case, he brought his Javanese-accented stress while pronouncing the English words. He is a Javanese as he was born and grew up in Solo. Solo is one of the regions in central Java that still has very strong Javanese culture. Most of the Solonese use Javanese to communicate (Jackson \& Rahmat, 2013, p. 143). Javanese as their mother tongue has a very specific accent, which is different from other countries; Javanese pronounce some consonants /d/, /b/, and /g/ with heavy stress or retroflex sounds.

Javanese brings its own characteristics such as dialect, accent, sound, stress, and intonation. The characteristics may influence the second or the third language. Therefore, it makes the uniqueness in pronouncing other languages; Indonesian and English. Thus, Javanese influences Mr. Joko Widodo in pronouncing some English vowels and consonants. In one of his official speeches of world meeting and conference, he pronounced about as /ə'bbot/ meanwhile, the correct pronunciation is /ə'baut/. He pronounced it with retroflex $/ \mathrm{b} /$ and the sound /av/as /o/.

It is very important to know the different pronunciation of the first language of a speaker that may influence the pronunciation of foreign languages. The mispronunciation of foreign languages because of the different pronunciation of the first language creates uniqueness in the pronunciation. This paper discussed the English consonants and vowels mispronounced by the seventh president of the Republic of Indonesia in his official English speeches and its influencing factors.

\section{Literature Review}

\subsection{Vowels, Diphthongs, and Triphthongs}

Fromkin, Robert, \& Hyams (2011, p. 585) defined, "vowel is a sound produced without significant constriction of the air flowing through the oral cavity". According to Yule (2014, p. 33), "vowel sounds are produced with a relatively free flow of air, and they are all typically 
voiced". He added, "to describe vowel sounds, we consider the way in which the tongue influences the shape through which the airflow must pass" (Yule, 2014, p. 33). Similarly, Ambalegin \& Suryani (2018, p. 80) mentioned "vowel sounds are produced by passing air through different shapes of the mouth with different position of the tongue and the lips and with the air stream relatively unobstructed by the narrow passages except at the glottis".

Kelly (2004, pp. 31-33) stated that based on the characteristics of the articulation, there are three categories of vowel sounds; closed vowel sounds (/i:/ /I/ / / /u:/), mid vowel sounds (/e/ /ə//3:/ / :/), and open vowel sounds (/æ/ / / /a:/ /p/). Kelly (2004, pp. 35-36) also mentioned that diphthong is the combination of two vowel sounds. Based on the characteristics of the articulation, there are three categories of diphthong sounds; centering diphthongs (/гә/ / ә/ /еə/), closing diphthong ending in /I/ (/еI/ /əI/ /aI/), and closing diphthong ending in / / / /əv/ /av/). McMahon (2002, p. 69) explained that vowels are indicated as long marked by symbol [:] and short vowel sounds.

Table 1 The anatomy of vowels (McMahon, 2002)

\begin{tabular}{|c|c|c|c|c|c|c|}
\hline \multicolumn{3}{|c|}{ The Front-Back Dimension } & \multicolumn{3}{|c|}{ The High-Low Dimension } & \multirow{2}{*}{$\begin{array}{l}\text { Lip Position } \\
\text { Rounded }\end{array}$} \\
\hline Front & Back & Central & High & Low & Mid & \\
\hline $\begin{array}{l}\text { [I] kit } \\
\text { [ع] dress } \\
\text { [æ] trap } \\
\text { [i:] fleece } \\
\text { [eI] face }\end{array}$ & 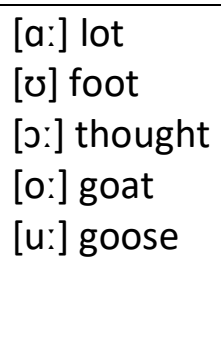 & $\begin{array}{l}\text { [ə] about } \\
{[3 r] \text { nurse }} \\
{[\wedge] \text { sturt }}\end{array}$ & $\begin{array}{l}\text { [I] kit } \\
\text { [i:] fleece } \\
\text { [v] foot } \\
\text { [u:] goose }\end{array}$ & $\begin{array}{l}\text { [æ] trap } \\
\text { [a:] lot }\end{array}$ & $\begin{array}{l}\text { [eI] face } \\
\text { [o:] goat } \\
{[\varepsilon] \text { dress }} \\
\text { [ग:] thought } \\
\text { [ə] about } \\
{[3 r] \text { nurse }} \\
{[\wedge] \text { strut }}\end{array}$ & $\begin{array}{l}{[\mho] \text { foot }} \\
{[\mathrm{J}] \text { thought }} \\
{[\mathrm{o:}] \text { goat }} \\
\text { [u:] goose }\end{array}$ \\
\hline
\end{tabular}

Roach (2012, p. 23) added that the most complex English sounds of the vowel type are the triphthongs. They can be rather difficult to pronounce, and very difficult to recognize. A triphthong is a glide from one vowel to another and then to a third, all produced rapidly and without interruption. The triphthongs can be identified as being composed of five close diphthongs with schwa /ə/. He lists the triphthongs erə (as in layer, player), arə (as in liar, fire), วгә (as in loyal, royal), әซə (as in lower, mower), and aøə (as in power, hour).

\subsection{Consonants}

Consonants are sounds made with a lot of constriction in the mouth, so that the air coming up from the lungs gets squashed. Fromkin et al. (2011, p. 560) stated, "consonant is speech sound produced with some constriction of the air stream". Consonant in English pronunciation is included in segmental phonemes (Low, 2015, p. 63). In English, consonant divides into two basic positions: voiced and voiceless. The voiced sound is produced when the vocal folds are drawn together, the air from the lungs repeatedly pushes them apart as it passes through, creating a vibration effect, meanwhile, the voiceless sound is produced when the vocal folds are spread apart, the air from the lungs passes between them unimpeded (Yule, 2014, p. 27).

Low $(2015$, p. 66) mentioned there are 24 consonants in British English sound system in which there are fifteen voiced consonants $(/ \mathrm{b} /, / \mathrm{d} /, / \mathrm{d} /, / \mathrm{g} /, / \mathrm{v} /, / \mathrm{d} /, / \mathrm{z} /, / 3 /, / \mathrm{m} /, / \mathrm{n} /, / \mathrm{h} /$, $/ \mathrm{l} /, / \mathrm{r} /, / \mathrm{w} /$, and $/ \mathrm{j} /)$ and nine voiceless consonants $(/ \mathrm{p} /, / \mathrm{t} /, / \mathrm{t} /, / \mathrm{k} /, / \mathrm{f} /, / \theta /, / \mathrm{s} /, / \mathrm{J} /$, and $/ \mathrm{h} / \mathrm{h}$. 
English Vowels and Consonants Mispronunciation of the Seventh President of Republic of Indonesia in His Official English Speeches and Its Influencing Factors, Ambalegin, Tomi Arianto

Table 2 The consonants (Low, 2015)

\begin{tabular}{cccccc}
\hline \multicolumn{7}{c}{ Consonants } \\
\hline $\mathbf{p}$ & Pin & $\mathbf{F}$ & Fan & $\mathbf{h}$ & hello \\
$\mathbf{b}$ & Bin & $\mathbf{V}$ & Van & $\mathbf{m}$ & more \\
$\mathbf{t}$ & To & $\mathbf{O}$ & Think & $\mathbf{n}$ & No \\
$\mathbf{d}$ & Do & $\mathbf{D}$ & The & $\mathbf{n}$ & Sing \\
$\mathbf{k}$ & cow & $\mathbf{S}$ & Sun & $\mathbf{I}$ & Live \\
$\mathbf{g}$ & got & $\mathbf{Z}$ & Zoo & $\mathbf{r}$ & Red \\
$\mathbf{t}$ & church & $\mathbf{J}$ & She & $\mathbf{j}$ & Yes \\
$\mathbf{d} 3$ & judge & $\mathbf{3}$ & Measure & $\mathbf{W}$ & wood \\
\hline
\end{tabular}

Further, McMahon (2002, p. 26) illustrated how to identify the voiced and voiceless consonants, and she said:

If you put your fingers on your 'Adam's apple' or 'voicebox' (technically the larynx), and produce a very long [zzzzzzz], you should feel vibration; this shows that $[z]$ is a voiced sound. On the other hand, if you make a very long [sssssss], you will not feel the same sort of activity: [s] is a voiceless sound.

Table 3 Place of articulation (McMahon, 2002)

\begin{tabular}{lclc}
\hline No & $\begin{array}{c}\text { Place of } \\
\text { Articulation }\end{array}$ & \multicolumn{1}{c}{ Descriptions } & Phoneme \\
\hline 1 & Bilabial & Top lip + bottom lip & $/ \mathrm{p} /, / \mathrm{b} /, / \mathrm{m} /$ \\
2 & Labio-dental & Bottom lip + the front top teeth & $/ \mathrm{f} /, / \mathrm{v} /$ \\
3 & Dental & Teeth + tongue & $/ \theta, / \mathrm{d} /$ \\
4 & Alveolar & Tongue (tip/blade) + alveolar ridge & $/ \mathrm{t} /, / \mathrm{d} /, / \mathrm{h} /, / \mathrm{l} /, / \mathrm{r} /, / \mathrm{s} /, / \mathrm{z} /$ \\
5 & Postalveolar & Tongue (blade) +alveolar ridge, hard palate & $/ \mathrm{t} /, / \mathrm{d} /, / \mathrm{J} /, / 3 /$ \\
6 & Palatal & Tongue (front) + the hard palate & $/ \mathrm{j} /$ \\
7 & Velar & Tongue (back) + the soft palate & $/ \mathrm{k} /, / \mathrm{g} /, / \mathrm{h} /, / \mathrm{x} /$ \\
8 & Glottal & Vocal cord & $/ \mathrm{h} /$ \\
\hline
\end{tabular}

\subsection{Factors Influencing Pronunciation}

Ambalegin \& Suryani (2018, p. 66) showed, "mother tongue has clear influence on learning L2 pronunciation, while mother tongue-like accent is interfering the English pronunciation; on the other hand, phonology deals with one's knowledge of the sound system of a language, then it concerns with a competence".

Kenworthy (1987, pp. 4-7) mentioned there are factors that affect pronunciation.

\section{i. The native language}

The more differences of sound characteristics of the native language from English, the more difficulties L1 speakers will find to pronounce English.

\section{ii. The age factor}

This factor is contradictory. Some researchers found that age determines the accuracy of a learner's pronunciation; other researchers argued that age confers no immediate advantage in pronouncing foreign sounds.

\section{iii. Amount of exposure}

It is tempting to view this simply as a matter of whether the speaker is living in an English-speaking country or not. If this is the case, then the speaker is 'surrounded' by English and this constant exposure should affect pronunciation skills. 


\section{iv. Phonetic ability}

This skill has been variously termed 'aptitude for oral mimicry', 'phonetic coding ability' or 'auditory discrimination ability'. Researchers have designed a set of tests which can measure this ability and have demonstrated that some people are able to discriminate between two sounds better than others, and/or are able to mimic sounds more accurately.

\section{v. Attitude and identity}

It has been claimed that factors such as a person's 'sense of identity' and feelings of 'group affiliation' are strong determiners of the acquisition of accurate pronunciation of a foreign language.

\section{Research Method}

This research used a phonological approach. This research focused on analyzing the English vowels and consonants mispronunciation. It is a descriptive qualitative research. This research started from the observation of the phenomena of pronunciation found in the official English speeches delivered by the seventh president of the Republic of Indonesia, Mr. Joko Widodo. The object of this research was English vowels and consonants pronounced, and the data source was all of the words pronounced by the seventh president of the Republic of Indonesia in his official English speeches; APEC CEO Summit 2014 in China, The World Economic Forum on East Asia 2015, and The World Press Freedom Day 2016.

In collecting the data, the researchers applied observation method by using uninvolved conversation observation technique (Sudaryanto, 2015 pp. 203-204). In analyzing the data, this researchers applied identity method by Sudaryanto $(2015$, p. 15$)$ in terms of articulatory phonetic identity, which aimed to support the analysis.

\section{Results and Discussion}

\subsection{The Mispronunciation of the Vowels and Consonants}

The data found were analyzed by using online Oxford dictionary as a tool to identify the mispronunciation of vowels and consonants.

Table 4: The data taken from the speech of APEC CEO Summit 2014

\begin{tabular}{|c|c|c|c|c|}
\hline \multirow{2}{*}{ No } & \multicolumn{3}{|c|}{ TRANSCRIPT } & \multirow{2}{*}{ Phonemes } \\
\hline & The Words & Standard RP & Mispronunciation & \\
\hline 1. & Ladies & /leidız/ & /ledis/ & /eI/, /z/ \\
\hline 2. & First & /fə:st/ & /fə:s/ & $/ \mathrm{t} /$ \\
\hline 3. & Government & /g^vəm(ə)nt/ & /g^vəm(ə)n/ & $/ \mathrm{t} /$ \\
\hline 4. & The & /ðі:/ , /ðә/ & /də/ & /ð/ \\
\hline 5. & Thank & /Oank/ & /tenk/ & $/ \theta /$ \\
\hline 6. & Presentation & /prez(ə)n'ter $\int(ə) n /$ & /persen terf(ə)n/ & /z/ \\
\hline 7. & Today & /tə'deI/ & /to'de/ & /ə/, /ег/ \\
\hline 8. & Very & /veri/ & /feri/ & /v/ \\
\hline 9. & With & /wIð/ & /wit/ & /ð/ \\
\hline 10. & Businessman & /biznismən/ & /bisnismen/ & $|z|$ \\
\hline 11. & Ago & /ə'gəઇ/ & /ə'gว/ & /əच/ \\
\hline 12. & So & /səu/ & /so/ & /əठ/ \\
\hline 13. & This & /ðIs/ & /dis/ & /ð/ \\
\hline 14. & Because & /br'kbz/ & /br `os/ & $/ \mathrm{D} /, / \mathrm{z} /$ \\
\hline 15. & About & /ə'bavt/ & / ə'bot/ & /av/ \\
\hline
\end{tabular}




\begin{tabular}{|c|c|c|c|c|}
\hline 16. & Business & /biznəs/ & /bisnis/ & /z/, /ə/ \\
\hline 17. & Show & 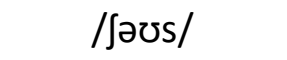 & /sow/ & $/ \int /, / \partial \mho /$ \\
\hline 18. & Have & /hav/ & /haf/ & /v/ \\
\hline 19. & Distance & /dist(ə)ns/ & /dıst(ə)n/ & /s/ \\
\hline 20. & Population & /pрpjひ'ІеI(ə)n/ & /рэрә'le」(ә)n/ & /p/, /j/, /ei/ \\
\hline 1. & London & /I^ndən/ & /londən/ & /^/ \\
\hline 22. & Thousand & /Өavz(ə)nd/ & /taus(ə)nd/ & $/ \theta /$ \\
\hline 23. & National & /naf(ə)n(ə)l/ & /nafIэnsl/ & /ə/ \\
\hline 24. & Sixty & /sıksti/ & /sıkti/ & $/ \mathrm{s} /$ \\
\hline 25. & Consumptive & /kən'sım(p)tiv/ & /kכn's^mtiv/ & /ə/ \\
\hline 26. & Fertilizers & /fə:tI|^Izəs/ & /fərtIl^Isəs/ & $/(r) /, / z /$ \\
\hline 27. & Build & /bIld/ & /bId/ & /I/ \\
\hline 28. & Water & /wo:tə/ & /wıtə/ & /נ:/ \\
\hline 29. & Supply & /sə'plıI/ & /su'plnI/ & /ə/ \\
\hline 30. & Area & /દ:rıə/ & /^:rع^/ & /દ/, /ıә/ \\
\hline 31. & Fisherman & /fIfəmən/ & /fisərmen/ & /S/, /ə/ \\
\hline 32. & Micro & /m^Ikrəひ & /m^Ikro:/ & /əठ/ \\
\hline 33. & Enterprise & /عntəpr^Iz/ & /Entəpr^Is/ & /z/ \\
\hline 34. & Help & /help/ & /hep/ & /I/ \\
\hline 35. & Refrigerator & /ri'fridzəreitə/ & /rə'fridzoretər/ & /eI/ \\
\hline 36. & Health & 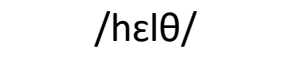 & /het/ & $/ \mathrm{I} /, / \theta /$ \\
\hline 37. & Program & /prougram/ & /pro:gram/ & /əఠ/ \\
\hline 38. & Infrastructure & /Infrastr^kt]ə/ & 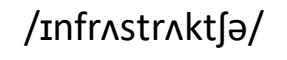 & /ə/ \\
\hline 39. & Opportunity & /ppə'tju:ntti/ & /oportju:nıti/ & /D/, /ə/ \\
\hline 40. & Capacity & /kə'pasıti/ & /ka'pasıti/ & /ə/ \\
\hline 41. & Seventeen & /sev(ə)nti:n/ & /sعf(ə)nti:n/ & $/ \mathrm{v} /$ \\
\hline 42. & Potential & 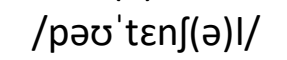 & /po'tenf(ə)l/ & /əठ/ \\
\hline 43. & Also & /ว:Isəv/ & /^lss:/ & /১:/,/əひ/ \\
\hline 44. & Maritime & /marit^Im/ & /merit $\wedge \mathrm{Im} /$ & /e/ \\
\hline 45. & Agenda & /ə'dzendə/ & /^'dzend $\Lambda /$ & /ə/ \\
\hline 46. & Cost & /knst/ & /kos/ & $/ \mathrm{p} /, \mathrm{t} /$ \\
\hline 47. & Only & /əonli/ & /onle/ & /əఠ/ \\
\hline 48. & Vessel & /vعs(ə)!/ & /fعs(ə)l/ & /v/ \\
\hline 49. & Example & /Ig'za:mp(ə)I/ & /ek'sa:mp(ə)l/ & $\mid z /, / g /$ \\
\hline 50. & Around & /ə'raund/ & /ə'ron/ & /av/ \\
\hline 51. & Megawatt & /megəwot/ & /meg^wot/ & /ə/, /p/ \\
\hline 52. & Zones & /zəon/ & /dzon/ & |z/ \\
\hline 53. & Manufacture & /manju'fakt]ə/ & /mano'faktor/ & $/ \mathrm{j} /, / \mathrm{t} \mathrm{J} /, / \partial /$ \\
\hline 54. & Complain & /kəm `plein/ & /kom `plen/ & /ə/,/eI/ \\
\hline 55. & Acquisition & /akwı' zis(ə)n/ & /akwi'sıJ(ə)n/ & /z/ \\
\hline 56. & Push & /pv]/ & /pos/ & $/ \mathrm{J} /$ \\
\hline 57. & Experience & /Ik'spiəriəns/ & /ek'spərıən/ & /гә/ \\
\hline 58. & Governors & /g^v(ə)nə/ & /g^v(ə)rnor/ & $\mid r /, / \partial /$ \\
\hline 59. & Outer & /avtər/ & /วtər/ & /av/ \\
\hline 60. & Unfinished & /^n'finift/ & /^n'finis/ & $/ \mathrm{J} /, \mathrm{t} /$ \\
\hline 61. & Accept & /ək'sept/ & /^k'sept/ & /ə/ \\
\hline 62. & Grown & /grəon/ & /gron/ & /əठ/ \\
\hline
\end{tabular}




\begin{tabular}{|c|c|c|c|c|}
\hline 63. & Lunch & $/ \operatorname{l\wedge n}(\mathrm{t}) \int /$ & /lnns/ & $/ \int /$ \\
\hline 64. & Problem & /probləm/ & /probləm/ & $/ \mathrm{p} /$ \\
\hline 65 & Month & $/ \mathrm{m} \wedge \mathrm{n} \theta /$ & /m^n/ & $/ \theta /$ \\
\hline 66. & Serve & /sə:v/ & /sə:f/ & $/ \mathrm{v} /$ \\
\hline 67. & Finally & /'f^Inəli/ & /'f^ınəle/ & /i/ \\
\hline 68. & Again & /ə'gein/ & /^`gen/ & /eI/ \\
\hline 69. & Waiting & /wertin/ & /weting & /ei/ \\
\hline
\end{tabular}

Table 5: The data taken from the speech of The World Economic Forum on East Asia 2015

\begin{tabular}{|c|c|c|c|c|}
\hline \multirow[t]{2}{*}{ No } & \multicolumn{3}{|c|}{ TRANSCRIPT } & \multirow[t]{2}{*}{ Phonemes } \\
\hline & The Words & Standard (RP) & Mispronunciation & \\
\hline 1. & Gentlemen & /dzent(ə)Imən/ & /dzent(ə)Imen/ & /ə/ \\
\hline 2. & World & /wə:Id/ & /wo:d/ & /ə/, /I/ \\
\hline 3. & Fundamental & /f^ndə'ment(ə)l/ & /fond^ 'ment(ə)I/ & $/ \Lambda /, / \partial /$ \\
\hline 4. & Emerging & /I'mə:d3In/ & /e'mə:d3In/ & /I/ \\
\hline 5. & Suddenly & /sıd(ə)nli/ & /s^d(ə)nle/ & /i/ \\
\hline 6. & Very & /veri/ & /feri/ & /v/ \\
\hline 7. & Opportunity & /opə'tju:nnti/ & /oportju:ntti/ & /o/,/ə/ \\
\hline 8. & Excellencies & /عks(ə)I(ə)nsis/ & /Ekselensis/ & /ə/ \\
\hline 9. & With & /WIठ/ & /wit/ & /す/ \\
\hline 10. & Prime & /pr^Im/ & /prem/ & /^I/ \\
\hline 11. & Today & /tə'deI/ & /to`de/ & /ə/, /eI/ \\
\hline 12. & Leadership & /li:dəJıp/ & /li:dərsip/ & $/ r /, / \int /$ \\
\hline 13. & Asia & /ег]ə/ & /^IIN/ & /eI/, /ə/ \\
\hline 14. & Thing & /Oin/ & /tin/ & $/ \theta /$ \\
\hline 15. & Fast & /fa:st/ & /fes/ & $/ a / t /$ \\
\hline 16. & Because & /bI'kdz/ & /bi`kos/ & $/ \mathrm{b} /, / \mathrm{z} /$ \\
\hline 17. & Every & /عvri/ & /عfri/ & /v/ \\
\hline 18. & Month & $/ m \wedge n \theta /$ & /m^n/ & $/ \theta /$ \\
\hline 19. & Within & /WIઇ'in/ & /WIt'in/ & /ð/ \\
\hline 20. & Task & /ta:sk/ & /ta:s/ & /k/ \\
\hline 21. & Reinvent & /ri:in'vent/ & /re:In'vent/ & /i/ \\
\hline 22. & Have & /hav/ & /haf/ & /v/ \\
\hline 23. & Seventies & /scv(ə)ntis/ & /scf(ə)ntis/ & /v/ \\
\hline 24. & Crude & /kru:d/ & /gru:d/ & /k/ \\
\hline 25. & Secretary & /sckrıt(ə)ri/ & /sckretıri/ & /I/, /ə/ \\
\hline 26. & Devalue & /di:'valju:/ & /de:'valju:/ & /i/ \\
\hline 27. & Currency & /k^r(ə)nsi/ & /kırınsi/ & /ə/ \\
\hline 28. & Again & /ə'gein/ & /^`gen/ & /eI/ \\
\hline 29. & Crashed & /kraft/ & /kres/ & $/ \mathrm{J} /, / \mathrm{t} /$ \\
\hline 30. & Begin & /bi'gin/ & /bI'gen/ & /I/ \\
\hline 31. & Industrialized & /In'd $\wedge$ striə|^Izt/ & /In'dustriles/ & 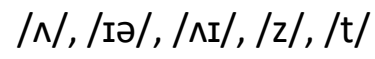 \\
\hline 32. & Build & /bild/ & /bid/ & /I/ \\
\hline 33. & Chemical & /kعmIk(ə)l/ & /t $\int \varepsilon \operatorname{mik}(\partial) \mathrm{l} /$ & /k/ \\
\hline 34. & Commodity & /kə'modrti/ & /ko'modrti/ & /ə/, /p/ \\
\hline 35. & Shall & /Jal/ & /sel/ & /S/ \\
\hline 36. & Reaches & /ri:t]Is/ & /re:t]es/ & /i/, /I/ \\
\hline
\end{tabular}




\begin{tabular}{|c|c|c|c|c|}
\hline 37. & Neglected & /nI'glektıd/ & /nə'glektıd/ & /I/ \\
\hline 38. & Today & /tə'deI/ & /to’de/ & /ə/, /eI/ \\
\hline 39. & Without & /wIđ'aut/ & /wit'art/ & /ð/ \\
\hline 40. & Recognize & /rekəgn^Iz/ & /rekogn^Iz/ & /ə/ \\
\hline 41. & Around & /ə'raond/ & /a'ron/ & /av/ \\
\hline 42. & Survive & /sə'v八IV/ & /surf^If/ & /ə/,/v/ \\
\hline 43. & Vibrant & /v^Ibr(ə)nt/ & /f^Ibr(ə)nt/ & /v/ \\
\hline 44. & Diversity & /dr'və:sIti/ & /dI'fərsıti/ & $/ \mathrm{v} /$ \\
\hline 45. & Fifth & /fff $\theta /$ & /fep/ & /ө/ \\
\hline 46. & Confidence & /kpnfId(ə)ns/ & /konfind(ə)n/ & $/ \mathrm{p} /, \mathrm{s} /$ \\
\hline 47. & Prevail & /pri'veil/ & /pri'frl/ & /e/, /ei/ \\
\hline 48. & Especially & /ع'spef(ə)li/ & /ع'spef(ə)le/ & /i/ \\
\hline 49. & Journey & /dzə:ni/ & /dzo:ney/ & /ə/ \\
\hline 50. & Thank & /Oank/ & /tenk/ & $/ \theta /$ \\
\hline
\end{tabular}

Table 6: The data taken from the speech of The World Press Freedom Day 2016

\begin{tabular}{|c|c|c|c|c|}
\hline \multirow[t]{2}{*}{ No } & \multicolumn{3}{|c|}{ TRANSCRIPT } & \multirow[t]{2}{*}{ Phonemes } \\
\hline & The word & Standard (RP) & Mispronunciation & \\
\hline 1. & Director & /dr'rektə/ & /di'rektor/ & /ə/ \\
\hline 2. & Honorable & /pn(ə)rəb(ə)l/ & /honวrəb(ə)l/ & /p/, /ə/ \\
\hline 3. & Official & /ə'fII(ə)l/ & /ว'fIJ(ə)l/ & /ə/ \\
\hline 4. & Delegates & /dzligəts/ & /dələgəts/ & /ع/, /I/ \\
\hline 5. & Around & /ə'raund/ & /ə'ron/ & /av/ \\
\hline 6. & Evening & /i:v(ə)nIn/ & /i:f(ə)nIn/ & /v/ \\
\hline 7. & Journalism & /dzə:n(ə)|Iz(ə)m/ & /dzz:n^lis(ə)m/ & /ə/, /z/ \\
\hline 8. & World & /wə:Id/ & /wo:d/ & /ə/, /I/ \\
\hline 9. & Asian & /eIf(ə)n/ & $/ \wedge \int i \wedge n /$ & /ei/, /ə/ \\
\hline 10. & Seven & /sદv(ə)n/ & /sદf(ə)n/ & /v/ \\
\hline 11. & Very & /veri/ & /fعri/ & /v/ \\
\hline 12. & Serious & /sıərıəs/ & /sərıəs/ & /Іә/ \\
\hline 13. & Economy & /I'kbnəmi/ & /e’kənวmi & /I/, /D/, /ə/ \\
\hline 14. & Confused & /kən'fju:zd/ & /kon'fju:s/ & $/ \partial /, / z /, / d /$ \\
\hline 15. & The & /ði:/ , /ðə/ & /də/ & /ð/ \\
\hline 16. & Thing & /OIn/ & $/ \operatorname{tin} /$ & $/ \theta /$ \\
\hline 17. & Democracy & /di'mokrəsi/ & /de'mokrəsi & $/ \mathrm{I} /, / \mathrm{D} /$ \\
\hline 18. & Grown & /grəon/ & /gron/ & /əठ/ \\
\hline 19. & Three & /Ori:/ & /tri/ & $/ \theta /$ \\
\hline 20. & Have & /hav/ & /haf/ & /v/ \\
\hline 21. & Global & /gləə઼b(ə)l/ & /glob(ə)l/ & /əఠ/ \\
\hline 22. & Regularly & /regjələli/ & /regularle/ & /j/, /ə/, /i/ \\
\hline 23. & Without & /wIঠ'avt/ & /wit'avt/ & /ð/ \\
\hline 24. & Role & /rəol/ & /rol/ & /əठ/ \\
\hline 25. & Government & /g^vəm(ə)nt/ & /g^vəm(ə)n/ & $/ \mathrm{t} /$ \\
\hline 26. & Accountable & /ə'kauntəb(ə)l/ & /ə'kəఠntəb(ə)I/ & /av/ \\
\hline 27. & Exposing & /عk'spəəzin/ & /ع'sposin/ & /k/, /əひ/, /z/ \\
\hline 28. & Fighting & /f^ItIn/ & /f^Igtin/ & /g/ \\
\hline 29. & Corruption & /kə'r^p $\int(\partial) n /$ & /kJ'r^p $\int(\partial) n /$ & /ə/ \\
\hline
\end{tabular}




\begin{tabular}{|c|c|c|c|c|}
\hline 30. & Media & /mi:dıə/ & /mə:dIN/ & /i/, /ıә/ \\
\hline 31. & Even & /i:v(ə)n/ & /i:fen/ & /v/ \\
\hline 32. & Gentlemen & /dzent(ə)Imən/ & /dz๕nt(ə)Imen/ & /ə/ \\
\hline 33. & Today & /tə'dei/ & /tv`de/ & /ə/, /eI/ \\
\hline 34. & Raise & /reiz/ & /r^IS/ & /ei/, /z/ \\
\hline 35. & Populism & /pppjひlız(ə)m/ & /pэpひlis(ə)m/ & $/ \mathrm{p} /, / \mathrm{j} /, / \mathrm{z} /$ \\
\hline 36. & Confront & /kən'frınt/ & /kon'fron/ & $/ \partial /, / \Lambda /, / t /$ \\
\hline 37. & Commentator & /knməntertə/ & /koməntetor/ & /ei/, /ə/ \\
\hline 38. & Overcome & /əひvə'k^m/ & /วvə'k^m/ & /əひ/ \\
\hline 39. & Shall & /Jal/ & /sel/ & $/ \mathrm{J} /$ \\
\hline 40. & Again & /ə'gein/ & /^`gen/ & /ei/ \\
\hline 41. & Tonight & /tə'n^It/ & /tu'n^It/ & /ə/ \\
\hline 42. & Prize & /prAIz/ & /pr^Is/ & $|z|$ \\
\hline 43. & Thank & /Oank/ & /tenk/ & $/ \theta /$ \\
\hline
\end{tabular}

\subsection{The Factors Influencing the Mispronunciation}

Factors influencing the mispronunciation of English vowels and consonants started from the information of Mr. Joko Widodo's background related to the education background, work experience, and language acquisition. He was from Javanese family. He was born and grew up in Surakarta, a city in the northeast of Yogyakarta (Hollar, 2018). When he was a child, he and his family lived in illegally built shacks near the city's flood-prone Solo River. He spent his study in Yogyakarta and Surakarta. He attended public primary school and public high schools. Then, he attended at Gadjah Mada University majoring of forestry in Yogyakarta (Suroso, 2012, p. 246). He spent his life in Java for more than 50 years until he was appointed as a governor of DKI Jakarta. Suroso's book illustrated that he used to use Javanese to communicate with others and his family (Suroso, 2012). Javanese is a daily language of Javanese society and in primary schools in Solo and Yogyakarta (Hamdani as cited in Saddhono \& Rohmadi, 2014, p. 25). Jackson \& Rahmat (2013, p. 143) stated, "mostly local residents in Surakarta and Solo speak Javanese rather than other languages". The characteristic of Javanese is that the consonant $/ \mathrm{b} /, / \mathrm{d} /, / \mathrm{g} /, / \mathrm{d}_{3} / / \mathrm{d} /$ are pronounced with Javanese-accented stress or retroflex sounds (Hakim, 2012, p. 247).

Javanese accented-stress influences Javanese while they are speaking Indonesian or foreign language. Subandowo (2017, pp. 205-206) stated that there are factors influencing while sounding English vowels and consonants such as, mother tongue, the concept of interference, mother tongue interference, concept of pronunciation, English language learning, and speaking ability. Having Mr. Joko Widodo's pronunciation of English vowels and consonants been analyzed, it was found that he was not able to pronounce the consonant

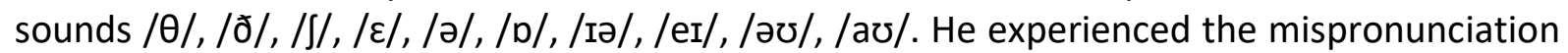
of English consonants and vowels because of some factors. The factors are as follows:

\section{i. Mother tongue interference.}

Mr. Joko Widodo is a Javanese. As a Javanese, he brings very thick Javanese-accented stress when he communicates. Thus, it influences his pronunciation when he speaks a second or third language.

\section{ii. Sound system differences between Indonesian and English.}

Indonesian language has 24 consonants and 6 vowels meanwhile English has 24 consonants and 12 vowels. The organs of speech of Indonesians are not trained to produce such unfamiliar sound systems of English. 
English Vowels and Consonants Mispronunciation of the Seventh President of Republic of Indonesia in His Official English Speeches and Its Influencing Factors, Ambalegin, Tomi Arianto

\section{iii. The same sound in the same spelling.}

The way he pronounced some English words is the same as that he pronounced Indonesian words. Mr. Joko Widodo did not realized such relationships between sound and spelling; he mispronounced words by just looking at their spellings e.g. population is pronounced as /pppjo'leI $(\partial) \mathrm{n} /$. The consonant sound / $\mathrm{j} /$ in the middle of the word is pronounced but it was pronounced as the spelling itself; fighting is pronounced as /f^ItIn/. The consonant sound / $\mathrm{g} /$ in the middle of the word is not pronounced, but he pronounced it as the spelling itself.

\section{iv. Educational background}

Mr. Joko Widodo spent mostly his study in Indonesia. He started his study in public primary school where English was not learned. He spent his high schools also in Java in public junior and senior high schools. He learnt English in high schools once in a week for two hours. He attended at Gajah Mada University majoring in forestry. Thus, English was not learnt specifically as a major subject.

\section{v. Environmental background}

Mr. Joko Widodo lived in Surakarta where the Javanese culture was still respected and applied as norms in Javanese's life. The Javanese are used to communicating among them in Javanese. It makes the Javanese have Javanese-accented stress. It definitely influences him to pronounce foreign languages.

\section{Conclusion}

The English mispronunciation was found in the seventh president of the Republic of Indonesia's official English speeches. These phenomena were caused by some factors based on his personal background. Based on the data which had been analyzed, it was found that the consonant sounds $/ \theta /, / \delta /, / \mathrm{v} /, / \mathrm{z} /, / \mathrm{J} /$ were pronounced incorrectly, the vowel sounds $/ \partial /, / \mathrm{p} /, / \varepsilon /, / \mathrm{i} /, / \mathrm{e} /, \mathrm{I} / \mathrm{l}$ were pronounced inconsistently, and the diphthong sounds /Iə/, /ei/, /əv/ and /av/ were pronounced incorrectly. The consonant sound / $/$ in the middle of the word was not pronounced. The consonant sound $/ \mathrm{j} /$ in the middle of the word was omitted. The consonant sounds $/ \mathrm{g} /, \mathrm{t} / \mathrm{t} / \mathrm{,} / \mathrm{r} /$ were pronounced as the spelling. The consonant sounds $/ \mathrm{t} / \mathrm{,} / \mathrm{s} / \mathrm{,} / \mathrm{k} /$ at the end of the word were omitted. The consonant [-y] sounded /I/ at the end of the word was pronounced as /e/. The diphthong sounds /Iə/, /eI/, /əv/ and /av/ were pronounced as $/ \mathrm{I} /, / \mathrm{N} / \mathrm{l} / \mathrm{\varepsilon} / \mathrm{,} / \mathrm{\partial} / \mathrm{,} / \mathrm{e} /$, and $/ \mathrm{\partial} /$. The factors influencing the English vowels and consonants mispronunciation of the seventh president of the Republic of Indonesia in his official English speeches were the mother tongue interference, the sound system differences between Indonesian and English, the influence of spelling in pronunciation, the educational background, and the environmental background.

\section{References}

Ambalegin, Suhardianto, \& Kaprawi, N. (2017). Obstacles facing learners in speaking English: Non-English teachers' perspective, Putra Batam School. Pertanika Journal Social Sciences \& Humanities, 25(1), $122 . \quad$ Retrieved from http://www.pertanika.upm.edu.my/

Ambalegin, \& Suryani, M. S. (2018). Mother tongue affecting the English vowel pronounciation of Batak Toba adults. In AICLL The 1st Annual International Conference on Language and Literature (pp. 66, 80). Medan: KnE Social Sciences \& Humanities. https://doi.org/10.18502/kss.v3i4.1920

Finegan, E. (2015). Language; Its structure and use (7th ed.). Stamford: Cengage Learning. 
Fromkin, V., Robert, R., \& Hyams, N. (2011). An introduction to language (9th ed.). Canada: wadsworth Cengage Learning. Retrieved from http://dinus.ac.id/repository/docs/ajar/intro_to_lang_fromkin.pdf

Gilakjani, A. P. (2016). English pronunciation instruction: A literature review. International Journal of Research in English Education, 1(1), 2. Retrieved from www.ijreeonline.com

Hakim, M. A. R. (2012). An analysis of phonetics b, d, g, j, ds and $\partial$ into English pronunciation for Java students ( A study on Java students at English Department on STAIN Bengkulu academic year 2011-2012). International Journal of Humanities and Social Science, 2(20), 244, 256. Retrieved from www.ijhssnet.com

Hollar, S. (2018). Joko Widodo president of Indonesia. Retrieved from https://www.britannica.com/biography/Joko-Widodo

Jackson, N., \& Rahmat. (2013). Decoding Basa Walikan - A preliminary analysis of Yogyakarta "reverse" language. International Journal of Indonesian Studies, 1, 143.

Kelly, G. (2004). How to teach pronunciation. England: Pearson Education Limited. Retrieved from www.longman.com

Kenworthy, J. (1987). Teaching English pronunciation. New York: Longman.

Low, E. L. (2015). Pronunciation for English as an international language (1st ed.). New York: Routledge Publishers.

McMahon, A. (2002). An introduction to English phonology. Edinburgh: Edinburgh Universiy Press. Retrieved from https://doi.org/10.1159/000328775

Roach, P. (2012). English phonetics and phonology; A practical course (4th ed.). Cambridge, UK: Cambridge University Press.

Saddhono, K., \& Rohmadi, M. (2014). A sociolinguistics study on the use of the Javanese language in the learning process in primary schools in Surakarta, Central Java, Indonesia. International Education Studies, 7(6), 25. https://doi.org/10.5539/ies.v7n6p25

Subandowo, D. (2017). The language interference in English speaking ability for Efl learners. International Seminar on English Language and Teaching, 205-206. Retrieved from ejournal.unp.ac.id/index.php/selt/article/view/8005

Sudaryanto. (2015). Metode dan aneka teknik analisis bahasa. Yogyakarta: Duta Wacana University Press.

Suroso, G. (2012). Sinopsis. In Jokowi si tukang kayu (p. 246). Jakarta: Ufuk Press.

Yule, G. (2014). The study of language (5th ed.). New York: Cambridge University Press.

Yulia, Y. (2014). An evaluation of English language teaching programs in Indonesian junior high schools in the Yogyakarta province. RMIT University.

\section{APPENDICES}

\section{Script Text of Video APEC CEO Summit 2014}

Ladies and gentlemen, all CEOs,

Good morning

First, on behalf of the Indonesian Government and the people of Indonesia, I would like to thank you for your coming to my presentation. Today, I am happy, I am very happy, to be 
English Vowels and Consonants Mispronunciation of the Seventh President of Republic of Indonesia in His Official English Speeches and Its Influencing Factors, Ambalegin, Tomi Arianto

among with you, because you know I was a businessmana years ago. So, this morning, I am very happy because we can talk about business, about investmentwith all of you.

The picture shows you our map of Indonesia. We have population of 240 million and the distance is like from London in UK to Istanbul in Turkey. And imagine we have 17,000 islands, 17,000 islands. (Thousand)

Our national budget on 2015 is $\$ 167$ (sixty) billion and for fuel subsidy is $\$ 27$ billion. It's huge. So, we want to channel our fuel subsidy from consumption to the productive activities, from consumptive activities to productive activities. We want to channel our fuel subsidy to the farmer for seeds, for fertilizers, and also for irrigation. And we want to build the dams 25 dams in 5 years from our fuel subsidy to maintain the water supply to the farming area.

Some subsidy we want to channel to the fishermen, to give them boat engines, to give them refrigerators. We want to increase the income of the fishermen. Some fuel subsidy we want to channel to micro and small enterprise in the villages. We want to help them raise their working capital. And some subsidy we want to channel to the health program, the education program. And some subsidy we want to channel to infrastructure.

In 5 years we want to build 24 seaports and deep seaports. As you know, we have 17,000 islands, so we need seaports and we need deep seaports. And this is your opportunity: 24 seaports and deep seaports.

The picture shows you our Jakarta Port, Tanjung Priok port. In 2009, the capacity is 3.6 million TEUs a year, and our plan in 2017 (seventeen) is around 15 million TEUs a year. This is the potential ports in Indonesia. This is your opportunity. We want to build in Sumatera island, in Kalimantan island, in Java island, in Sulawesi island, in Maluku island, also in Papua island.

And we plan to build our railway track, railway network. Now we havealready in Java and we want to build in Sumatera island, in Kalimantan island, in Sulawesi island and also in Papua island. This is your opportunity.

Now we talk about mass transportation. We want to build our mass transportation in 6 big cities in Indonesia. We have started in Jakarta last year, and we want to build in Medan, in Makassar, in Semarang, in Bandung, in Surabaya. So, this is also your opportunity, because you know our national budget is limited.

Now we talk our maritime agenda. We want to build sea toll. What is sea toll? Sea toll is maritime transportation system to make our transportation cost lower, to make our transportation cost more efficient. We want to build from the west to the east. We hope not only the vessel can enter our sea toll but also mother vessels can enter the sea toll. So, the price, the cost of the transportation is more efficient.

For example, the price of the cement, one sack cement in Java island is $\$ 6$ per sack cement. But in Papua island the price is $\$ 150$ per sack cement. Imagine, 25 times. So we hope with our sea toll the price in our islands is the same.

Electricity, we need power plan. We need around 35,000 mega watt to build our industries, to build our projects, to build our industrial zones, our manufacture zones. So, we need power plan. This is also your opportunity to invest in this project, because we need our power plans for manufacturing for industrial zones.

Many investors, a lot of investors, when they come to me, almost of them they always complain about land acquisition. I will push my ministers, my governors, my mayors, to help clearing this problem. I have experience with land acquisition when I was a governor. We have a project, the Jakarta Outer Ring Road, started 15 years ago but is stopped 8 years ago, because we have a problem here: 1.5 kilometers unfinished because there is 143 families do 
not accept with the compensation price. So last year I invite them. I go to the grown then I invite them for lunchand dinner, four times. Ah, this is me. I invite them and then we talk about the problem, four times, four times meeting. And the problem is cleared. And now the toll road has been used 7 month ago.

Now we talk business permit. We have national one-stop service office that can help you, that will serve you, that will facilitate you, that will give you your business permit. For example, principle business permit needs 3 days to process.

Finally, again on behalf of the Indonesian government and the people of Indonesia, I would like to thank you for your listening(to) my presentation. We are waiting for you to come to Indonesia. We are waiting for you to invest in Indonesia.

\section{Script Text of Video The World Economic Forum on East Asia 2015}

\section{Ladies and Gentlemen}

The world is in a fundamental transition, for us in Indonesia and for all emerging market the condition is suddenly very challenging but when we see challenges I see opportunity. In fact, our challenges are your opportunities.

Your excellencies, ladies and gentlemen. I have just returned from official visits to Tokyo and Beijing, after many meetings with President Xi Jinping and Prime Minister Shinzo Abe I would like to share with you I am extremely optimistic. I believe China and Japan today enjoy the best leadership we have had in generation, and I believe this is to the great benefits of Asia as a whole. If there is one thing that Prime Minister Abe presidency and I can agree on it is that the world is changing very fast. China is changing, Japan is changing and Indonesia is changing. I believe that Indonesia has to change. Why do I believe that Indonesia has to change? Because my people tell me, my people tell me that our country has to change every week and every month I go into the villages. I go into the cities, and my people ask me Mr. Jokowi please change our country.

Within this global transition, our task is clear. We have to reinventour economies. We have to reinvent our societies. Let me share with you a story. We have been here before in the 1970s (seventies). Indonesia became rich on export of crudeoil. Crude oil was booming. Oil price is recordedhigh. At that time, Indonesia was the only member of OPEC from Asia. Our energy minister Subroto was secretary general OPEC. Then in 1980, the price of crude oil is pressed. By then oil and gas export were 80 percent from our total export. We were forced to devalue our currency. We have an economic crisis but with crisis came an opportunity, again with crisis came opportunity. Afterthe 1980, oil prices crashed, Indonesia begin to industrialized. Over the next 15 years, we build up textile and garment industry, furniture industry, pulp and papers industry, palm oil industries, chemical industries.

By 1995, oil and gas exports were only 30 percent of our total exports. Export of goods and services were 70 percent. Today we are in the same situation. Commodity prices have crashed. Our currency has been hit. This is causing a lot of pain for a lot of people. But let me tell you. We have done it before. And we shall do it again. Our commodity reaches with us over consumptive. We neglected our human resources. Our currency the rupiah has been shaken. Today we must see from consumption back to production, from consumption to investment, investment in our infrastructure, investment in our industry but most importantly investment in our human capital the most precious resource in the $21^{\text {st }}$ century. Change can be painful, change will create winner or losers but there can be no progress without change. It can be no gain without pain. Even with pain, my people tell me every 
English Vowels and Consonants Mispronunciation of the Seventh President of Republic of Indonesia in His Official English Speeches and Its Influencing Factors, Ambalegin, Tomi Arianto

week and every month. Please Mr. Jokowi change our country. Our people are very wise. They recognize that to have progress, they must be sacrifice. Fortunately, story is on our side, I would even say God is on our side.

After 1997, Asian Financial crisis, a lot of people around the world asked, will the Indonesian people survive? Today almost 20 years later. We are a vibrant and stable democracy. Our unity in diversity what we call Bhinneka Tunggal Ika is stronger than ever.

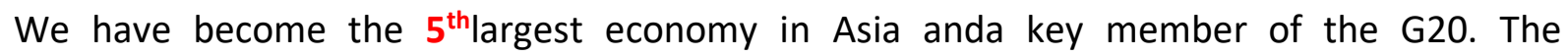
Indonesian people are wise. They are resourcefuland therefore, I am here to tell you with one hundred percent confidence Indonesia will prevail. Again one hundred percent confidence Indonesia will prevail. When you spent time with Indonesia especially on facebook or twitter you will find our people have incredible humor, our people have incredible courage, our people have incredible wisdom. Therefore, Ladies and gentlemen, I stand here today to invite you to join me and my people on an incredible journey and an incredible adventure to make incredible profits and if you have any problem, call me.

Thank you. Thank you.

\section{Script Text of Video The World Press Freedom Day 2016}

Assalamualaikum Wr. Wb.

Your recency, Mr. Amosurta, former President of Timor Leste, your recency, director jenderal of UNESCO Mr. Irene Bocofa, honorable ministers, senior official and delegates, and most important of all honorable members of the press from around the world.

Ladies and gentleman good evening and welcome to Indonesia home of the most free and most high energy journalism in the world.

When the Asian financial crisis of 1997 (Seven) hit Indonesia, the situation was very very serious. Our economy declined by minus fifteen percent in one single year. Our society became confused, our future became uncertain, but born from that crisis were all the things which today make Indonesia a strong and dynamic society. Democracy, a market-oriented economy and most importantly political freedom including the freedom of expression and freedom of the press.

Since the Asian financial crisis on 1997 the Indonesian economic has grown by more than three hundred percent. We have had no less than four. Based full on transfer of power in the last twenty years. Global service regularly shows that Indonesian are among the most optimistic societies in the world. I want to say to you members of our national press and to you members of the international press we could not have done this without you. Once again, we could not have done this without you.

Since the era of reformacy in the late 1990s, a free and energic, energetic press has played a critical important role in holding government accountable, in exposing, and therefore fighting corruption, and in keeping all of us entertaint. Democracy is dynamic and you, our friends in the media have make democracy even more dynamic.

Ladies and gentlemen, today world journalism faces perhaps the greatest challenges in a generation. Hoax, fakes news, hate speech, we are seeing the raise of populism still too many journalist and writers face persecution in many parts of the world. Every time we confront such challenges many commentators say, the world is coming to an end, to them I say you are just too young to remember. We will overcome, we have done it before and we shall do it again. 
Lastly, I would like to congratulate tonight winners of the Gulliermo Canno prize, Mrs. Betle and to all of you, and to all of us of very happy world press freedom day.

Note: the words colored show the imspronunciation English vowels and consonants 